\title{
Information in EU Security and Defence
}

Citation for published version (APA):

Dijkstra, H. (2014). Information in EU Security and Defence. In T. Blom, \& S. Vanhoonacker (Eds.), The Politics of Information: The Case of the European Union (pp. 229-241). Palgrave Macmillan.

https://doi.org/10.1057/9781137325419_15

Document status and date:

Published: 30/06/2014

DOI:

10.1057/9781137325419_15

Document Version:

Early version submitted to journal

Document license:

Unspecified

\section{Please check the document version of this publication:}

- A submitted manuscript is the version of the article upon submission and before peer-review. There can be important differences between the submitted version and the official published version of record.

People interested in the research are advised to contact the author for the final version of the publication, or visit the DOI to the publisher's website.

- The final author version and the galley proof are versions of the publication after peer review.

- The final published version features the final layout of the paper including the volume, issue and page numbers.

Link to publication

\footnotetext{
General rights rights.

- You may freely distribute the URL identifying the publication in the public portal. please follow below link for the End User Agreement:

www.umlib.nl/taverne-license

Take down policy

If you believe that this document breaches copyright please contact us at:

repository@maastrichtuniversity.nl

providing details and we will investigate your claim.
}

Copyright and moral rights for the publications made accessible in the public portal are retained by the authors and/or other copyright owners and it is a condition of accessing publications that users recognise and abide by the legal requirements associated with these

- Users may download and print one copy of any publication from the public portal for the purpose of private study or research.

- You may not further distribute the material or use it for any profit-making activity or commercial gain

If the publication is distributed under the terms of Article $25 \mathrm{fa}$ of the Dutch Copyright Act, indicated by the "Taverne" license above, 


\title{
Information in EU Security and Defence
}

\author{
Submitted chapter to Tannelie Blom and Sophie Vanhoonacker (eds) (2014) The Politics of \\ Information: The case of the European Union, Basingstoke: Palgrave Macmillan
}

\author{
Hylke Dijkstra
}

\section{INTRODUCTION}

The European Union (EU) has launched more than two dozen crisis management operations spread over three continents since 2003. It has sent uniformed personnel and monitors to conflict regions in the Western Balkans, sub-Saharan Africa and the Middle-East. It implements peace agreements, supports security sector reform, builds up local capabilities, carries out executive policing and even contributes to a 'safe and secure environment'. The EU oftentimes carries its mandate under risky circumstances. For the purpose of crisis management in the context of the Common Security and Defence Policy (CSDP) good quality information is thus an absolute requirement. Good quality information is required to inform advance and crisis response planning. It is needed during the conduct of the operations as well.

The EU member states have created a complex system of information functions in the area of foreign policy over the last forty years (Nuttall 1992; Smith 2004; Dijkstra and Vanhoonacker 2011; Bicchi 2011, 2012, Bicchi and Carta 2012). They engage in extensive information-sharing, including through the Correspondance européenne (COREU), they have established informationprocessing bureaucracies in Brussels, and the EU increasingly gathers information autonomously of its member states. How the EU and its member states gather and process information in security and defence is, needless to say, important. Information is inherently political (Blom in this volume) and the constitution of the EU information system affects the relations between member states as well as relations between the national and EU level.

When taking a closer look at the organization of information functions throughout the CSDP process, there is puzzling variation. While some information functions are organized at the level of the member states, others take place at the EU-level, while still other information functions are shared between the EU and its member states. Advance planning, particularly contingency planning, which prepares the EU for crises, is mainly a member states affair. Member states gather information of all sorts through their national embassies and intelligence services. They use this information, in turn, to inform their EU policies. For the subsequent crisis response planning, however, the member states have delegated most information-processing and some informationgathering to the Brussels bureaucracies. During the implementation of crisis management operations, the headquarters in one of the member states or in NATO provide information. ${ }^{1}$

This chapter asks why information functions are organized at the national, EU or at both levels throughout the CSDP policy process? It shows that the member states face a trade-off between the efficiency gains of delegating information functions to the EU level and the risk of sovereignty loss. As a result, information functions are located in the EU in areas where the member states did not have credible functional alternatives. The chapter starts with a discussion of the

1 On the CSDP planning process, see in detail Grevi (2009), Mattelaer (2010) and Dijkstra (2013). 
organization of information in security and defence, after which it empirically analyses the different phases of the CSDP policy process.

\section{THE ORGANIZATION OF INFORMATION IN SECURITY AND DEFENCE}

When it comes to the politics of information in the EU, Tannelie Blom (in this volume) makes the useful distinction between the constitutive and operational politics of information. The constitutive politics of information is concerned with the formal and informal institutionalization of information functions. It matters a great deal, for instance, if information in the CSDP domain is automatically available to all member states, is limited to troop contributing member states, or is distributed on a 'need to know' basis. If access to information is restricted, this will put some actors in a favorable political position vis-à-vis other actors. Rules and practices that affect the gathering and processing of information are thus likely to be subject to political contestation and EU negotiations.

The operational politics of information is concerned with how actors use their information advantages to manipulate EU policy processes. It may relate, of course, to the constitutive politics of information, as the latter by definition affects the distribution of information among actors, but it does not only deal with the consequences of constitutive politics. For example, COREUs are shared among all the member states (constitutive politics), but this does not automatically mean that all the member states are equally capable of successfully using COREU information in EU policy-making (operational politics). Some member states may have more administrative capacity and additional, alternative, sources of information. Some coordinate better domestically and some may have better diplomats. The constitutive politics thus only provides half of the picture.

By asking why information functions are organized at the national, EU or at both levels throughout the CSDP policy process, this chapter is quintessentially interested in the constitutive politics of information. As will be shown in the remaining sections of this chapter, the member states have made a number of explicit choices about how to organize information functions in the CSDP. These choices clearly affect day-to-day policy-making and the relations between member states. The constitutive politics of information in the CSDP is thus important and it is worth analyzing on its own terms.

In answering the research question, this chapter takes a rationalist approach. Rational choice institutionalism provides us with a sophisticated toolkit to study the division of competences among the different levels of the EU - national, shared, or supranational (e.g. Franchino 2007). The case of the CSDP will make clear that the organization of information functions in the EU follows familiar logics discussed in the principal-agent literature. Member states make constant trade-offs between the efficiency gains of delegating information-gathering and processing functions to the EU versus the accompanying sovereignty costs. Sovereignty costs and the loss of full control over information vary considerably across the policy process (Bradley and Kelley 2008) and this variation helps us to understand why information functions have been delegated differently.

The starting assumption of rationalist theory is that the EU member states make cost-benefit calculations in determining which information functions they carry out themselves and which they delegate (Keohane 1984; Pollack 1997; Thatcher and Stone Sweet 2002). Jonas Tallberg (2002: 25) elegantly notes, in this respect, that the member states "face the choice of whether to perform the desired functions 'in house' or to 'outsource' them". Only when the costs of keeping functions in house exceed the costs of outsourcing, the member states will organize information functions at the EU level. The main challenge for rationalists is therefore to identify the costs and benefits of having these functions at the national and EU levels.

The benefits of outsourcing information functions to the EU are relatively straightforward. The centralization of information functions may yield many efficiency advantages (Abbott and Snidal 1998; Koremenos, Lipson and Snidal 2001; Pollack 2003). By organizing informationgathering, for example, through EU embassies rather than through 27 national channels, one can do with less bureaucracy. Alternatively, member states can divide the labour, focus on niche topics and share information (Dijkstra and Vanhoonacker 2011). In addition to cost-cutting, sharing and 
delegation may lead to specialization gains and credibility (Abbott and Snidal 1998; Hawkins et al. 2006). For information-processing, it may be more efficient to have have one expert bureaucracy in Brussels rather than equivalent bureaucracies in all of the national capitals. There is thus a strong functional rationale for organizing information functions at the EU level.

The centralization of information, needless to say, also involves sovereignty costs (Abbott and Snidal 2000; Epstein and O'Halloran 2008; Dijkstra 2013). Information, after all, is a scarce resource and rationalists note that information surpluses typically lead to power and influence (e.g. Pollack 1997; Majone 2001; Tallberg 2002, 2006; Hawkins et al. 2006). By delegating information functions to the EU level, the member states thus inevitably empower the EU level. In the words of David Lake and Matthew McCubbins (2006: 343) "no pain, no gain". The anticipated loss of sovereignty, including through unintended consequences, is something that the member states take into account during their delegation decisions. They are thus reluctant to delegate in the first place (Stone 2011). This is particularly the case in the very sensitive field of security and defence, where uncertainty is high and the loss of sovereignty seen as one of the greatest threats (Dijkstra 2013).

The delegation of information functions, however, does not imply that sovereignty costs will spill out of control (bureaucracy runaway thesis). The member states are likely to establish control mechanisms to prevent excessive influence by the EU level (Hawkins et al. 2006). One method is to engage in direct monitoring through national 'shadow' bureaucracies, which perform many of the same functions as the EU bureaucracies (Lake and McCubbins 2006). This partially undermines the efficiency rationale and is thus rather expensive. Yet it is for rationalists the major rationale why in the EU various information functions are duplicated or are shared between the national and the supranational level. Member states can furthermore rely on third party information. They can also limit the incentives for shirking through appointment procedures in the EU bureaucracies and secondments of officials. Control is thus organized via formal and informal means (Stone 2011).

In conclusion, rational choice institutionalism provides a parsimonious explanation for why information functions are organized at different levels in the CSDP. As such it has potentially many important things to say about the constitutive politics of information in the European Union. If the task of gathering and processing information has been delegated to the EU-level, this will affect the power relations between EU officials and the member states. If member states considered the costs of delegation too high and continue to carry out information functions themselves, this will instantly leave the EU-level at a disadvantage. The following sections will empirically discuss the different phases of the CSDP policy process and analyze how the member states have organized the relevant information functions.

\section{ADVANCE PLANNING}

The CSDP process starts with advance planning. The objective of advance planning is to get a headstart before conflicts escalate. This allows for rapid reaction and quick deployment. Advance planning comes in two categories: generic and contingency planning (see European Union 2008; Mattelaer 2010; Simon 2010). The former involves drawing up concepts and standard pre-identified scenarios as well as accompanying capabilities catalogues (e.g. which member state has helicopters that can be used during humanitarian operations in Sub-Saharan Africa). The latter is about continuously monitoring the security situation around the world, drafting country-specific scenarios and possible deployment options (ibid.). Contingency planning is therefore much more detailed than generic advance planning.

Generic planning can theoretically be a very sensitive exercise. Explicit choices have to be made about the level of ambition in terms of deployments. What type of missions are on the table? Only advisory and peacebuilding operations in Africa, or also preemptive interventions without a UN Security Council Resolution? And what about countering a Russian intervention in Georgia or the Baltic states? Defining the scope of EU crisis management action is, needless to say, a political task. The EU has, in this context, adopted the Petersberg tasks in the Treaty of Amsterdam of 1997 (article J.7). The Petersberg tasks are relatively broad - from humanitarian and rescue tasks to 
peacemaking. They define the overall scope of EU action. The Lisbon Treaty of 2009 laid down the 'extended' Petersberg tasks (article 43 TEU) based on the first experiences with CSDP. The member states have thus defined the level of ambition in very general terms. Making really explicit choices have proved too difficult. EU bureaucracies are not involved in this respect.

In terms of information management, generic planning is a lot less sensitive because it does not involve actual operational decisions. It is about drafting crisis management procedures, military and civilian scenarios and developing a force catalogue. Such generic tasks can easily be delegated, which is exactly what happened in the case of the EU. Following the Helsinki European Council of 1999, the member states established military and civilian crisis management directorates and a EU Military Staff (EUMS) in Brussels (Dijkstra 2013). These bureaucratic bodies spent most of the initial years on generic planning and getting all the procedures in order (see Giegerich 2008). The draft documents written by the EU agents were subsequently discussed with the member states, which formally had to approve them. ${ }^{2}$

Contingency planning, in contrast, is one of the most sensitive tasks when it comes to the organization of information functions in the EU. As it is detailed, concerns third states, and informs crisis response decisions, it is a sensitive process. It has to take place in secret, which naturally results in restrictions on information access. It is thus no surprise that member states have been very reluctant to delegate information-gathering and processing tasks for the purpose of contingency planning. They have been wary that Brussels officials prepare all sorts of scenarios leading to informational advantages when it comes to actual decision-making. One officer from the United Kingdom, for instance, notes that "advance planning in the EU has to be very, very general; not specific, data-based, rather than operational based. This is the UK perspective, because it limits the extent to which the EUMS can build a planning empire" (interview in Simon 2010: 20). To professionally engage in contingency planning, the EU would need to have a standing Operations Headquarters, which the member states have so far refused. ${ }^{3}$

While extensive contingency planning has not been delegated, there are several limited cases of autonomous EU information-gathering. One implication of the Treaty of Lisbon is, for example, that the EU delegations have been tasked to increase their political reporting. For many of the involved officials, this has been a real change of culture (Bicchi 2012). Though political reporting is naturally quite different from reporting on CSDP issues. Contingency planning is further informed by ad hoc reports from the EU Special Representatives (Grevi 2007). Moreover, the Intelligence Analysis Centre (INTCEN) issues intelligence reports mainly based on information shared by the national liaison officers. Simon Duke (in this volume) gives an excellent overview of some cases of autonomous information-gathering.

The problem is, however, not only that information-gathering for advance planning is rather limited. It also concerns information-processing. The EUMS was only equipped with a Military Assessment and Planning (MAP) branch in 2008, which employs a handful of officials (Simon 2010). France furthermore pushed strongly for the creation of the Crisis Management Planning Directorate (CMPD) to improve reaction times to crises, but it neither qualifies as a professional capability in terms of contingency planning. Particularly the contrast to NATO is strong. After all, NATO employs several thousands of officers for contingency planning in its military headquarters, traditionally to draft plans to counter a Soviet intervention. In the words of one NATO civil servant, "we have contingency planning for every conceivable contingency, particularly relating to territorial defence; so yes, I sleep well at night" (presentation, Brussels, 2011).

To conclude on advance planning, because it is such a sensitive area with high sovereignty costs, member states have been very reluctant to delegate to the EU-level a substantial capability for CSDP contingency planning. The absence of a permanent headquarters is important in this respect. Without any headquarters, it is difficult to carry out advance planning in a secretive manner. The

2 Contrary to most CSDP documents, many concepts are publicly available. This indicates the lack of sensitivity.

3 The recent French intervention in Mali is a case in point. For several years, France has had secretive contingency planning ready for an intervention. When the crisis went from bad to worse, French troops could be very quickly deployed. The EU, by contrast, does not have a standing military headquarters to monitor the situation and plan in so much detail. This automatically leads to delays in the CSDP policy process. 
EU officials currently have to compile documents from the limited sources they have at their disposal. This strongly undermines the capabilities for rapid response. It is only after a crisis is emerging that the EU gets involved and starts writing option papers. On a theoretical level, it is important to note that when it comes to the absence of advance planning in the EU, it is plausible to argue that the member states, and the United Kingdom in particular, have made conscious nondelegation choices. This fits in well with the rationalist explanation outlined above.

\section{CRISIS REPONSE PLANNING}

A short options paper - drafted by the EU institutions and describing in general terms the alternative courses of action - typically marks the end of advance planning. On this basis the Political and Security Committee can take the decision that "EU action is appropriate" and delegate planning authority to the CMPD of the EEAS. This means that crisis response planning begins. It implies that the EU starts preparing an actual CSDP operation. Crisis response planning is substantially different from secretively considering various scenarios for intervention (contingency planning). During the process of crisis response planning, the parameters of EU engagement are increasingly defined, the definite option is chosen and the details are filled in. In the initial phase, the EU-level is in the lead. In the final phases, planning takes place in the military or civilian headquarters.

The CMPD has the responsibility of drafting a Crisis Management Concept (CMC). This is the first formal planning document in the CSDP process. In order to draft this Concept, the CMPD engages in substantial information-gathering. It typically consults with key EU member states and relevant international organizations. It can also rely on the regional expertise in the EEAS, the network of EU delegations across the globe, and the assessment reports of INTCEN. For intra-EU exchange, the EEAS Crisis Platform regularly meets bringing together all the relevant actors. Most importantly, however, is the fact-finding mission to the ground. CSDP officials from the CMPD and other services in the EEAS make up the large majority of the mission, which can be regarded as an instance of autonomous information-gathering (Dijkstra and Vanhoonacker 2011; Dijkstra 2013).

The rationale for putting the EU officials at the heart of the fact-finding mission is functional to a large extent. As they write the CMC, it is necessary for them to have first-hand information on the situation on the ground. The mission generally includes a policy officer, planner, logistical civil servant and an intelligence officer (interviews with EU officials 2009). They stay on the ground for a week. The fact-finding mission is thus critical for gathering information that informs the CMC. However, it does not substitute the advance planning. Some of the key member states are likely to have at least as good an overview of the political and security situation due to their unilateral and bilateral channels. French intelligence in Sub-Saharan Africa is, for example, superior to anything that EU officials can gather in a week. Variation in the administrative capacity of the member states thus need to be accounted for.

After the CMC has been drafted (often in consultation with key member states) it is released to the member states, which will analyze it in their capitals. They will cross-reference the proposal against their own information and preferences, which results in instructions for their permanent representations in Brussels. The draft $\mathrm{CMC}$ will be discussed in the Political and Security Committee as well as in the respective underlying EU Military Committee and Committee of the Civilian Aspects of Crisis Management (CIVCOM). Once it is approved at the bureaucratic level, it will go to the Council of Ministers, which has the final say (Mattelaer 2010; European Union 2002).

After approval of the CMC and the parameters of a possible intervention have been written down, crisis response planning gets more detailed. It stays at the EU level. Depending on whether the potential crisis management operation will be military or civilian in character, the EU Military Staff or the Civilian Planning and Conduct Capability (CPCC) become the lead services (Grevi 2009). They are both part of the EEAS. They will start writing the draft Military, Police or Civilian Strategic Options. These are the second official planning documents. These Strategic Options generally outline three or four possible options for EU engagement (Mattelaer 2010). They include 
the mission mandate, an initial overview of the requirements, and an initial budget of the common costs in the case of military operations.

When writing the draft Strategic Options, EU officials draw on the preliminary work done for the CMC. By working on the more detailed Strategic Options, they bring their content expertise to the process. Information-processing is thus key at this stage. Following the adoption of the Strategic Options, the military planning moves to the Council Decision, which is the formal legal basis of the operation, while in the civilian process the Concept of Operation (CONOPS) is the next step (Mattelaer 2010). While the military Council Decision is mainly a codification of the previous planning document, it does include a detailed financial reference amount for the common costs. The EU bureaucracies will send all these documents to the member states. They will form the basis of the negotiations between the member states, which still have the final word.

The Council Decision determines the (military) Operations Headquarters and the Operations Commander. The EU can use, in this respect, the NATO Headquarters or headquarters in selected member states. For civilian missions, the CPCC automatically acts as the Operations Headquarters. The first major task is to draft the CONOPS. Since there is a gap between the bureaucracies in Brussels and the military headquarters, the EU sends liaison officers to the Operations Headquarters in order to inform the military leadership about the political background of the mission (interview with EU official 2010). In practice, the EU bureaucracies stay closely involved and are the first point of contact for the political decision-makers of the member states in Brussels.

The CONOPS is a detailed operational document, which precisely lists the mandate of the mission and a range of logistical issues. It is accompanied by a Statement of Requirements, which forms the basis of force generation. Force generation is a process, consisting of different rounds, in which the Operations Commander asks the member states to make contributions to the mission. It can take a week in cases of emergency, but typically lasts a long time, because contributions are, of course, expensive for the member states. For civilian CSDP operations, personnel is recruited on an individual basis, which requires significant administration. Once this process is completed, the Operations Commander sends his Operations Plan (OPLAN) to the member states. If they agree, they effectively launch the mission.

In conclusion one can state that information-gathering and processing during crisis response planning is shared between the member states and the EU bureaucracies. For functional reasons, the first planning documents are drafted in Brussels. They are based on information provided by the member states and gathered by EU officials during, for example, the fact-finding mission. What is striking is that the key member states have typically kept their own information-gathering channels in place and do much of the same information-processing in order to keep the EU officials under control. That national capitals, which have a strong interest in particular regions of the world, invest in such shadow bureaucracies to autonomously assess the work of EU officials is well-explained by rationalist principal-agent literature. The member states balance between the functional requirement of doing response planning efficiently and the continuous fear of losing control.

\section{CONDUCT OF OPERATIONS}

During the actual conduct of operations, the Force Headquarters (or Mission Headquarters in the civilian missions) on the ground is the key source of information. It consists of 100-200 officers who deal with all sorts of things such as the permanent monitoring of the CSDP operation, handling logistics and administration, and political liaison with the host country and third actors. One of its tasks is also to draft regular and incident reports. The Rule of Law Mission in Kosovo (EULEX), for instance, has a dedicated unit for this purpose. These reports are sent through the Operations Headquarters (in NATO, the member states, or the Civilian Planning and Conduct Capability in the case of civilian missions) to the political decision bodies in Brussels.

Needless to say, information is filtered at the different levels. The Force Headquarters has more (detailed) information than the Operations Headquarters, which in turn has more information than the European External Action Service, which again has more information than the diplomats 
and military officers in the Permanent Representations. It is, for instance, telling that most member states only have one civilian desk officer in Brussels who has to follow up to a dozen operations in the member states committees. Many of the tactical day-to-day decisions thus do not reach Brussels and many member states have to be satisfied with weekly and monthly mission reports. Typically, furthermore, the Force and Operations Commanders visit Brussels (only) once every six months for a more extensive discussion with the member states.

What is important, however, is that the formal chain of command is not the only information process during the conduct of operations. There are many informal and parallel processes going on. One important process is information sharing and coordination on the ground. In Bosnia or Kosovo, for instance, many of the member states have bilateral embassies. They share information with the CSDP mission, but also gather and process information themselves and file diplomatic telegrams to the capitals and the permanent representations in Brussels. This limits the extent to which the member states are dependent on information coming through the official EU channels. On the other hand, the Western Balkans may be an outlier. In more remote places, such as Aceh and Chad, fewer member states have information access, which makes control more difficult.

Finally, it is important to note that Brussels-based officials and national diplomats as well as ministers and capital-based civil servants regularly go on field trips. Visiting the CSDP operation on the ground allows for direct information-gathering. While some of these high-level visits might be of a ceremonial nature, in which key mission officials brief defence ministers on the highlights of the CSDP operation, the everyday contacts at a lower level add considerable substance to the parallel process of information-gathering. Once again, it is important here to stress variation among the member states. Only member states with genuine interests are likely to invest in administrative capacity to have an independent assessment of the situation.

In conclusion, the member states have considered EU security and defence too sensitive to establish a permanent military headquarters in Brussels. Instead, they can use NATO facilities but mostly rely on ad hoc national headquarters. This also limits the extent to which they have to rely on the formal EU channels for information gathering and processing. Yet any act of delegation, even to national agents, leads to something less than full control. In this respect, the various informal information-gathering and processing channels are important. They allow for a direct channel between the CSDP mission and the formal decision-makers in the EU. Member states try to establish them to get first hand information rather than to rely on the formal channels of reporting. Both the formal choice for the headquarters and the informal channels are key features of the rationalist explanation.

\section{CONCLUSION}

The member states' wish to collectively deploy civilian and military instruments within the CSDP has put them for an interesting dilemma in terms of information functions. On the one hand, there is a strong functional pressure to centralize the gathering and processing of information in the interest of efficiency, neutrality, expertise, and continuity. On the other hand, there is a strong desire to keep full control and not to rely on other actors, which can use information surpluses to their advantage. When putting citizens in harm's way, member states both demand professionalism and sovereignty control. Unfortunately, they cannot have it all within a multilateral context.

This dilemma lies at the heart of the organization of the CSDP. The member states have only delegated information functions to the EU when absolutely necessary. This mostly concerns crisis response planning where EU officials are in the lead. The member states furthermore have accepted a certain unity of command during the conduct of operations, but have made the choice to entrust such command to a lead member states (or NATO) rather than to the EU bureaucracies in Brussels. As regards contingency planning, the most sensitive part of advance planning, the member states have decided to avoid delegation and to keep all the relevant functions in the capitals. This considerably undermines rapid EU deployment, but it has been a consequences that member states have been willing to accept. 
While member states have made a number of intentional choices about where to locate the information functions related to advance planning, crisis response planning and implementation, there does not exist a neat divide in competences between the EU and the member states. Indeed, even when the lead of crisis response planning is with the civil servants of the EU in Brussels, the member states might gather their own parallel information and do their own shadow planning. This is redundant from an efficiency perspectives and undermines the rationale for delegation in the first place, but it helps the member states to keep a tab on things.

What is interesting is the variation among the member states in their ability to establish such parallel information and planning bureaucracies. While this chapter has repeatedly highlighted this issue as a topic of importance, it has not systematically analyzed it. It would be a fruitful avenue for further research. Rationalist perspectives clearly identify a need for shadow bureaucracies, if the member states are to keep sufficient information control over the CSDP bureaucracies (Lake and McCubbins 2006). Yet shadow bureaucracies are costly to maintain. It is therefore likely that not all the member states will invest equally in parallel structures. Particularly the larger member states, which have stronger interests around the globe, may be eager to keep up their administrative capacity. This, in turn, also puts them at an advantageous position vis-à-vis the smaller member states.

The question that finally needs to be raised is whether this myriad of information functions is endemic to the CSDP or the field of security and defence in general. From a theoretical perspective, one would not expect other international organizations to differ greatly. While the amount of member states' control varies compared to the United Nations or NATO, the member states of these international organizations theoretically face similar information dilemma. Empirically, the United Nations seems to struggle with the same sorts of issues (Dijkstra 2012). The absence of a peacekeeping headquarters is even more pronounced. In NATO, however, as earlier mentioned, advance planning has been delegated. This is a topic that merits further research as well.

\section{ACKNOWLEDGEMENTS}

The research leading to these results has received funding from the People Programme (Marie Curie Actions) of the European Union's Seventh Framework Programme (FP7/2007-2013) under REA grant agreement $\mathrm{n}^{\circ}$ [298081].

\section{REFERENCES}

Abbott, K. and D. Snidal (1998) 'Why states act through formal international organizations', Journal of Conflict Resolution 42(1): 3-32.

Abbott, K. and D. Snidal (2000) 'Hard and Soft Law in International Governance', International Organization 54(3): 421-456.

Bicchi, F. (2011) 'The EU as a community of practice: foreign policy communications in the COREU network', Journal of European Public Policy 18(8): 1115-1132

Bicchi, F. (2012) 'The European External Action Service: A Pivotal Actor in EU Foreign Policy Communications', The Hague Journal of Diplomacy 7(1): 81-94.

Bicchi, F. and C. Carta (2012) 'The COREU Network and the Circulation of Information Within EU Foreign Policy', Journal of European Integration 34(5): 465-484. 
Bradley, C. and J. Kelley (2008) 'The Concept of International Delegation', Law and Contemporary Problems 71(1): 1-36.

Dijkstra, H. (2012), 'Efficiency versus Sovereignty: Delegation to the UN Secretariat in Peacekeeping', International Peacekeeping 19(5), pp. 581-596

Dijkstra, H. (2013) Policy-Making in EU Security and Defense: An Institutional Perspective, Basingstoke: Palgrave Macmillan.

Dijkstra, H. and S. Vanhoonacker (2011) 'The Changing Politics of Information in European Foreign Policy', Journal of European Integration 33(5): 541-558.

Epstein, D. and S. O'Halloran (2008) 'Sovereignty and Delegation in International Organizations', Law and Contemporary Problems 71(1): 77-92.

European Union (2002) Suggestions for procedures for coherent, comprehensive EU crisis management [Crisis Management Procedures], 8945/2/02

European Union (2008) EU Concept for Military Planning at the Political and Strategic Level, $10687 / 08$

Franchino, F. (2007) The Powers of Union: Delegation in the EU, Cambridge: Cambridge University Press.

Giegerich, B. (2008) Chapter One: EU Crisis Management: Ambitions and Achievements, Adelphi Papers 48(397): 15-34.

Grevi, G. (2007) Pioneering foreign policy: the EU Special Representatives, Paris: EU Institute for Security Studies.

Grevi, G. (2009) 'ESDP Institutions', in G. Grevi, D. Helly and D. Keohane (eds) European Security and Defence Policy: The First 10 Years (1999-2009), Paris: EU Institute for Security Studies.

Hawkins, D. et al. (eds) (2006) Delegation and Agency in International Organizations, Cambridge: Cambridge University Press.

Keohane, R. (1984) After Hegemony: Cooperation and Discord in the World Political Economy, Princeton: Princeton University Press.

Koremenos, B., C. Lipson and D. Snidal (2001) 'The rational design of international institutions', International Organization 55(4): 761-799.

Lake, D. and M. McCubbins (2006) 'The logic of delegation to international organizations', in D. Hawkins et al. (eds), Delegation and Agency in International Organizations, Cambridge: Cambridge University Press.

Majone, G. (2001) 'Two Logics of Delegation: Agency and Fiduciary Relations in EU Governance', European Union Politics 2(1): 103-122.

Mattelaer, A. (2010) 'The CSDP Mission Planning Process of the European Union: Innovations and Shortfalls', European Integration Online Papers 14. 
Nuttall, S. (2000) European Foreign Policy, Oxford: Oxford University Press.

Pollack, M. (1997) 'Delegation, agency, and agenda-setting in the European Community', International Organization 51(1): 99-134.

Pollack, M. (2003) The Engines of European Integration: Agency, Delegation, and Agenda Setting in the EU, Oxford: Oxford University Press.

Simon, L. (2010) 'Command and control? Planning for EU military operations', Occasional Paper 81, Paris: EU-ISS.

Smith, M.E. (2004) Europe's Foreign and Security Policy: The Institutionalization of Cooperation, Cambridge: Cambridge University Press.

Stone, R. (2011) Controlling Institutions: International Organizations and the Global Economy, Cambridge: Cambridge University Press.

Tallberg, J. (2002) 'Delegation to Supranational Institutions: Why, How, and with What Consequences?', West European Politics 25(1): 23-46.

Tallberg, J. (2006) Leadership and Negotiation in the European Union, Cambridge: Cambridge University Press.

Thatcher, M. and A. Stone Sweet (2002) 'Theory and Practice of Delegation to Non-Majoritarian Institutions', West European Politics 25(1): 1-22. 